\title{
Incorporation of the UN Convention on the Rights of the Child in National Law
}

\author{
Simon Hoffman \\ Swansea University, Swansea, Wales, UK \\ s.hoffman@swansea.ac.uk \\ Rebecca Thorburn Stern \\ Uppsala University, Uppsala, Sweden \\ rebecca.stern@jur.uu.se
}

\begin{abstract}
Incorporation is amongst the legislative measures of implementation of the UN Convention on the Rights of the Child (CRC) recommended by the Committee on the Rights of the Child. This article will discuss incorporation of the CRC in national law. It will show how incorporation is understood in different contexts, and highlight possible tensions between child rights and international law discourse and analysis. It begins by reviewing literature on incorporation of human rights treaties before discussing how incorporation is conceptualised in the context of the CRC. The focus then shifts to a review of studies that provide insights into how incorporation and legal integration of the CRC impact on how children's rights are treated in national legal systems. While primarily a commentary on the available literature, the authors reflect on the significance of incorporation and how this is understood for academic and legal analysis, and what the evidence tells us about its contribution to the realisation of children's rights.
\end{abstract}

\section{Keywords}

UNCRC - incorporation - implementation - children - children's rights - human rights 
A State Party to the UN Convention on the Rights of the Child (CRC) is required to undertake 'all appropriate legislative, administrative, and other measures' to implement the rights guaranteed to children (CRC, Article 4). ${ }^{1} \mathrm{Al}$ though a State party has no discretion and must comply with this obligation (UN Committee 2013, para.18; VCLT 1969, Article 26; HRC 1981, para. 1), in common with other international human rights treaties the CRC does not prescribe the means by which the CRC is to be implemented. A number of UN Treaty Monitoring Bodies (TMBs) have commented on mechanisms for the realisation of human rights, including through legal measures of implementation. For example, the Committee on Economic Social and Cultural Rights (CESCR) states that international human rights standards should 'operate directly and immediately' within the domestic legal system enabling individuals to seek enforcement of their rights (CESCR 1998, paras. 4-5). The CESCR does not expressly require incorporation of the International Covenant on Economic Social and Cultural Rights (ICESCR) in national law, but does comment that such an approach is desirable (ibid., para.8). The CESCR recommends 'direct incorporation' so that all the terms of the ICESCR are 'retained intact' in order to avoid potential problems of translating its provisions into national law (ibid., para. 6). The Human Rights Committee (HRC) takes the view that while incorporation of the International Covenant on Civil and Political Rights (ICCPR) in the domestic legal order is not an absolute requirement, it nevertheless invites States parties to consider incorporation in order to 'facilitate full realization of Covenant rights' (HRC 2004, para. 13). However, neither the ICESCR nor the HRC goes as far as to specify what is meant by the term "incorporation".

Incorporation is amongst the legislative measures of implementation discussed by the Committee in the Rights of the Child (the Committee) in General Comment No.5, General Measures of Implementation of the Convention of the Rights of the Child (UN Committee 2003). The Committee perhaps goes further than other TMBs to particularise what incorporation should imply for national legal systems, insisting that incorporation should mean the 'provisions of the [CRC] can be directly invoked before the courts and applied by national authorities and that the [CRC] will prevail where there is a conflict with domestic legislation or common practice' (ibid., para. 20). The Committee has also stated that ensuring the principles and provisions of the CRC can be directly applied

1 Article 4 is not the only CRC article to specify the manner in which rights are to be implemented; it is, however, a primary obligation applying to all CRC articles. 
and appropriately enforced is 'fundamental' (ibid., para. 2). It has been suggested that the Committee 'strongly encourages' incorporation, and prioritises this amongst the legal measures of implementation to be adopted by States (Kilkelly, 2019: 325; Hoffman, 2019). However, it has been noted that the Committee's approach may be at variance with legal tradition in many States (Thorburn Stern, 2019; Kilkelly, 2019) and it has been argued that insisting on primacy of the CRC often creates conflict with national law and practice (Hoffman 2019; Williams, 2012).

This article will discuss incorporation of the CRC in national law. It will highlight how the way in which incorporation is understood in different contexts differs, introducing tension between child rights and international law discourse and analysis. The article begins by reviewing literature on incorporation of human rights treaties before discussing how incorporation is conceptualised in the context of the CRC. The focus then shifts to a review of studies which provide insights into the impact of incorporation and legal integration of children's rights in national legal systems. While primarily a commentary on the available literature, the authors reflect on the significance of incorporation of the CRC and how this is understood for academic and legal analysis, and what the evidence tells us about its contribution to the realisation of children's rights.

While there is a rich literature on children's rights, comparatively little has been written on incorporation of the CRC in national law (edited collections on children's rights include: Tobin (ed.), 2019; Kilkelly and Liefaard (eds.), 2018; Ruck et al (eds.), 2017; Vandenhole et al (eds.), 2015; Williams and Invernizzi (eds.), 2011). It is therefore necessary to turn first to accounts of incorporation of human rights in international law discourse to develop an understanding of what this means. It is immediately apparent from the general literature that the meaning of incorporation is far from settled. Some accounts adopt a broad view in which incorporation may be understood as a variety of processes though which States 'internalize human rights treaties and absorb international human rights norms into the national legal system' (Alston and Goodman, 2013: 1047). Boyle, for example, describes incorporation as the 'domestic internalisation of international norms' through various 'pathways' which include: constitutionalising an international standard; the legislative or administrative adoption of international human rights norms; complying with the decisions 
of an international complaints mechanism; or, judicial incorporation through the common law' (Boyle, 2019: 9 drawing on Resnick, 2006). A narrower analysis, focusing specifically on the legal aspects of incorporation, is apparent from a 2014 report by the Venice Commission of the Council of Europe which examined the implementation of human rights treaties in domestic law in Europe and Latin America (Venice Commission, 2014). The Venice Commission identifies a diverse range of legal techniques deployed by States to incorporate international human rights treaties in national law, but suggests that the choice to incorporate a human rights treaty, and the technique adopted to do so, is largely dependent on whether a State demonstrates a monist or dualist system in relation to international law. The Venice Commission's report notes that in monist systems it is common practice for international treaties which a State has ratified to constitute part of the domestic legal order without the need for transposition by means of national legal instruments. This is contrasted with dualist systems which require international treaties to be transformed into national law by means of a statute or other national law, without which international law will not apply directly within the domestic legal order. Nollkaemper makes a similar distinction and speaks of 'automatic incorporation' whereby international law is made part of national law through the accepted operation of a written or unwritten rule, and 'transformation' of international obligations into national law through domestic legislation to make them enforceable by a domestic court as the two main approaches to making international law applicable on the national level adopted by states (Nollkaemper, 2011: 73-74; see also, Björgvinsson, 2016; Crawford, 2012). Incorporation through domestic legislation has also been described as domestication (Egede, 2007), legislative assimilation (Garcia Mendez, 2007), quasi-incorporation (Van Alstine, 2009), and sectoral incorporation (Lundy et al., 2012). A significant factor influencing how this terminology is deployed is how incorporation is understood at regional level. Leary suggests that automatic incorporation (in the same sense used by Nollkaemper) is the preferred approach in some European, African and Asian countries, and many Latin American countries (Leary, 1982). She opines that Commonwealth and Nordic countries ${ }^{2}$ are more likely to favour the use of national legislation to give effect to international norms at domestic level, referring to this as legislative incorporation (ibid.). In the Nordic countries, some commentators have noted that incorporation and transformation

2 The Scandinavian countries are: Sweden, Norway, Denmark (sometimes, but not always, Finland). The Nordic countries are: Sweden, Norway, Denmark Finland and Iceland. Usage varies, with English-speaking researchers tending to use "Scandinavia" generically. Here, the correct usage based on the relevant research is "Nordic" countries. 
are considered legal-technical terms with different meanings, the first referring to when an international treaty or parts of it become domestic law, the second being when national legislation is revised or amended to comply with the treaty obligations (see, for example, Bring et al., 2014; Scheinin, 1996).

A common starting point in literature describing the relationship between international law and national law, including in the examples mentioned above, is the distinction between monist and dualist legal systems (for example, Bjorgvinsson, 2016; Alston and Goodman, 2013; Crawford, 2012; Skelton, 2011; Heyns and Viljoen, 2001). This has become something of an orthodoxy even though in practice it is difficult to find a national legal system that is purely monist or dualist, and several authors have questioned the utility of the classification to analyse how incorporation takes effect and its impact on national legal systems. Verdier and Versteeg, for example, argue that the distinction has fundamental limitations for classifying national approaches to international law (Verdier and Versteeg, 2017). The Venice Commission's assessment is that the monist/dualist classification does not provide an adequate mechanism to determine the factors that influence the integration of a human rights treaty into domestic law, and many countries have features of both systems (Venice Commission, 2014). What emerges from general accounts of incorporation is a varied terminology to categorise how States seek to internalise international human rights instruments. Full discussion of this terminological variation is beyond the scope of this paper but it is worth noting that it reflects differences apparent between national legal systems on giving effect to international law at the domestic level, and demonstrates that there is no strict rule on how adherence to international human rights treaties is to be achieved in national law.

\section{3}

\section{Incorporation and Enforcement}

In April 2014 an Optional Protocol to the CRC on a Communications Procedure (OPIC) came into force. ${ }^{3}$ OPIC introduces a procedure enabling children or their representative to bring a complaint (communication) before the Committee provided a State Party to the CRC has also accepted the competence of the Committee to receive complaints through ratification or accession to the protocol. As at September 2019, only 134 of the 196 States Parties to the CRC had failed to take any action to sign or ratify opIC. ${ }^{4}$ The protocol has been

3 OPIC available here: https://www.ohchr.org/EN/HRBodies/CRC/Pages/CRCIndex.aspx.

4 Information available here: https://www.ohchr.org/Documents/HRBodies/CRC/OHCHR _Map_CRC-OP-IC.pdf. 
criticised, in particular for compromising the adjudication of economic, social and cultural rights to accommodate concerns raised by some States about the justiciability of these rights (Beco, 2013). Despite this, and the fact that a Committee decision under OPIC will not be enforceable against a State Party, Sandberg has suggested that it will result in decisions which, 'more accurately can draw the line between what is a right of the child and what is not ... [and it] is to be hoped that [it] will make the CRC a sharper legal tool to be used in the courts' (Sandberg, 2014: 20).

The Committee, in common with other TMBs, is not endowed with mechanisms to enforce treaties and so incorporation provides the means by which enforcement becomes possible via national, court-based adjudication (SmithCannoy, 2014; Oberleitner, 2012). Alston and Goodman note that incorporation is amongst the mechanisms deployed by the international system to compel States to comply with their human rights obligations (Alston and Goodman, 2013). But as Polonko et al observe in a study of law reform in the context of child maltreatment, the question of incorporation (of the CRC), and its status in the hierarchy of national legal norms, are distinct aspects of reform (Polonko et al., 2016). Whilst enforcement differs from incorporation, it is often discussed as an aspect of incorporation (for example, Oberleitner, 2012). Boyle argues that 'incorporation of international law into domestic law means embedding legal standards as set out in international law and making them enforceable at the domestic level' (Boyle, 2018: 10). Focussing on socio-economic rights, she cites a number of jurisdictions where this has underpinned litigation and enforcement by the courts. Similarly, Daly et al. refer to 'hard methods' of legal incorporation, 'characterised by the possibility of legal enforcement of rights through the courts' before going on to conclude that 'incorporation through domestic law remains the most effective means of ensuring compliance with human rights treaty obligations' (Daly et al., 2019: 5 and case study 2). Daly et al. note that incorporation leads to strong reliance by the courts (giving the example of incorporation of the CRC in Norway) (for discussion, see Sandberg, 2014; Søvig, 2009), and that constitutional incorporation is most effective to support progress on human rights because of the message it sends about the position of rights in the legal hierarchy. In contrast, others have noted that incorporation itself does not guarantee enforcement and that more may be needed before redress for human rights violations is available via the courts (for example, Skelton, 2018; see also contributions in Leifaard and Doek (eds.), 2015). In this respect, the distinction between monist and dualist systems may provide some (limited) insight into the likely impact of incorporation in different States. The Venice Commission notes a tendency in monist systems to grant human rights treaties a 'rather high status' in the national legal order (Venice Commission, 2014, para. 18). However, the Venice Commission recognises that 
monism does not automatically entail legal superiority of international law and comments that the justiciability of rights, 'depends solely on their nature and content' and not on any transposition into national law (ibid.).

\section{Incorporation and the $\mathrm{CRC}$}

Tobin notes that the Committee requires clarity as to whether or not the CRC is automatically incorporated into domestic law or whether separate legislation is required (Tobin, 2019: 115). Beyond this, the Committee avoids describing the means by which incorporation of the $\mathrm{CRC}$ is to be achieved, and instead focuses on what incorporation should mean in practice (see above, Introduction). The literature on incorporation of the CRC is limited, with the majority of studies carried out for UNICEF (for example Lundy et al., 2012; UNICEF, 2008; UNICEF, 2007a; UNICEF, 2007b; Alston and Tobin, 2005; UNICEF, 2004). These often begin with or recognise the distinction between monist and dualist systems, or between common law and civil law jurisdictions (for example UNICEF, 2008, 2007a, 2007b, Alston and Tobin, 2005). A study of the impact of the CRC in diverse legal systems by UNICEF discusses law reform in selected common law and civil law jurisdictions as well as in Muslim countries and plural legal systems (UNICEF, 2007a). Garcia Mendez, in her contribution to this research, comments that, 'legislative assimilation' is the route normally taken under common law jurisdictions whereas some form of constitutionalisation is favoured in civil law countries (Garcia Mendez, 2007). Other studies have introduced terminology to provide new ways of understanding incorporation in the context of children's rights. For example, a UNICEF study on law reform and the CRC refers to direct incorporation, describing this in terms consistent with the language used by the CESCR and the Committee's understanding of incorporation (UNICEF, 2007b). However, this research also refers to a sectoral approach to law reform whereby national legislation in different areas is amended or revised to ensure conformity with the $\mathrm{CRC}$, consistent with the transformative approach seen in, for example, Nordic countries (ibid.). An examination of legal implementation of the CRC in 12 countries by Lundy et al. for UNICEF-UK in 2012 introduces (or confirms) a typology of incorporation which seeks to capture the complexity of legal implementation encountered in practice (Lundy et al., 2012). This study refers to direct incorporation whereby the CRC is 'fully transformed' into domestic law at either legislative or constitutional level, 'indirect incorporation' whereby legal mechanisms give the CRC some effect in the domestic legal order, and 'sectoral incorporation' when relevant provisions of the CRC are transposed into relevant national sectoral laws (ibid.: 3). In a follow-up article in 2013, the study authors further 
explain that direct incorporation can involve transposition of the CRC into national legislation in full or in part: the latter being where select articles are transposed (Lundy et al., 2013).

The UNICEF study on law reform found that direct and automatic incorporation was more likely to be the norm in civil law jurisdictions, and far less likely in countries with a common law system (UNICEF, 2007b). The same study also found that (at the time) the CRC had been incorporated at a constitutional level in one-third of the $5^{2}$ countries examined, and directly into national law in the remaining two-thirds (ibid.). Similarly, a UNICEF study in 2004 examined 50 countries and found that most of these had incorporated the Convention, although it is apparent that in this research incorporation is used to include sectoral approaches (UNICEF, 2004). The study by Lundy et al. found that full and direct incorporation had taken place in just three of the 12 countries examined for that research, and of these only one (Spain) could be said to have incorporated the CRC into its constitution in its entirety (Lundy et al., 2012). Lundy et al. also found that in the majority of States, incorporation had been by way of indirect or sectoral approaches. In 2019 McCall-Smith's analysis of a number of country case studies using the typology set out in the Lundy et al. report confirms the prevalence of sectoral approaches (McCall-Smith, 2019).

\section{5}

\section{Indirect and Sectoral Approaches}

As noted in the introduction to this article, a direct approach to incorporation of the CRC will mean that its provisions may be directly applied and enforced. An alternative is indirect incorporation. This approach gives the CRC some legal effect within a national legal system but does not give rise to any rights which are directly enforceable before domestic courts or tribunals. This approach is discussed by Kilkelly in her 2019 article on transformative approaches to legal implementation of the CRC. She notes that indirect incorporation has led to States taking 'creative approaches designed to give the [CRC] further effect at national level' (Kilkelly 2019: 323). Pointing out that indirect incorporation may include legislation to require action at national level to give further effect to the CrC, Kilkelly gives the example of Ireland which has amended its Constitution to require provision to be made for the right of the child to be heard and the child's best interests to be given consideration in child care and family law proceedings (see also Harrington, 2007). Hoffman and Williams, writing on indirect incorporation in the context of devolution and multi-level governance in Wales, argue that Welsh legislation requiring Welsh Ministers to take account of the CRC in the exercise of their functions (to include policy 
and proposals for legislation) has introduced 'new rules of engagement' between government and children, meaning careful attention has to be given as to how to safeguard and promote children's rights (Hoffman and Williams 2013: 170). Kilkelly notes the potential of indirect incorporation to reinforce statutory implementation of the CRC, as well as to raise awareness about and support for more far-reaching implementation measures among decision-makers as they become 'sensitised to the merits of deeper incorporation', but nonetheless concludes that indirect incorporation 'falls short of giving substantive protection to children's rights at a constitutional level' (Kilkelly 2019: 7). In the broader context of international law, the indirect approach has much in common with what Van Alstine describes as quasi-incorporation or partial incorporation, as well as the legislative or administrative adoption of international human rights norms (Van Alstine, 2009). According to Van Alstine, quasi-incorporation means that domestic legislation is based on, or is subject to, international law obligations, or government departments and officials are required to take relevant human rights treaty obligations into account.

A number of commentators have identified an indirect interpretive route to incorporation of international law at national level. This is beyond the scope of this paper fully to explore, but it is worth noting Koh's observation that international norms become transformed or internalised in national law as States interpret and apply them at domestic level (Koh, 1999). Boyle identifies this as one of the pathways to internalisation of human rights, while Campbell argues that it is the mechanism by which the European Convention on Human Rights is incorporated into UK law (Boyle, 2018; Campbell, 2001). Campbell, commenting on the UK Human Rights Act 1998, argues that while this legislation is often seen as having fully incorporated the European Convention on Human Rights into UK law, this is misleading. Instead, Campbell argues, incorporation is 'largely confined to matters of interpretation' (Campbell, 2001: 80). Williams, writing on implementation of the CRC, takes a broad view of incorporation, arguing that the CRC may find its way into law through indirect means by absorption into jurisprudence, or as a point of reference for government policy, or even professional values or occupational standards (Williams, 2007; see also Williams, 2015). This absorption of the CRC into national law through an interpretive approach may be seen as a departure from formal understandings of incorporation. However, Hoffman has argued that a function of legislation to incorporate the CRC might be to establish child rights norms as the underpinning framework for government policy and Ministerial decision-making (Hoffman, 2019).

On sectoral incorporation a UNICEF study in 2008 found that consolidated children's statutes were 'fast emerging as a trend' among States Parties to the CRC (UniCeF, 2008: ii and 35-36). At the time of the study, 69 States Parties 
(from 193) had enacted consolidated children's statutes, i.e. legislation as general frameworks for the enactment of legislation to protect children, or legislation establishing such frameworks or make provision for children in particular sectors where children's rights are relevant. Sectoral law reform appears to be a significant aspect of legal implementation in many States. In 2007, UNICEF found this to be the 'prevailing trend', something confirmed by Lundy et al. in 2012 (UNICEF, 2007b: 103; Lundy et al.: 2012). Polonko et al. note that there is variation amongst States on which principles or rights are incorporated, and that these ranged from specific rights (e.g. health rights) to incorporation of general principles such as best interests (Polonko et al., 2016). A report by UNICEF in 2006 noted that greater progress is made toward incorporating rights that meet traditional notions of welfare-protection (e.g. health), than children's civil rights (e.g. privacy, freedom of expression) (UNICEF, 2006). Other studies have noted that the sectoral approach may result in the gradual adoption of the CRC over time (for example UNICEF, 2004). However, Polonko et al. suggest this is only in 'rare cases' (Polonko et al., 2016: 36). Lundy et al. found the sectoral approach was having 'mixed results' as reforming legislation tended to focus primarily on areas of child protection, the family and juvenile justice (Lundy et al., 2012: 19). While States will often claim that national sectoral law reflects the requirements of the CRC, this is disputed. Williams, for example, is sceptical and observes that, 'it is rare to find domestic reform explicitly based on the objectives generated by the textual system of the [CRC]' (Williams, 2012: 226). However, the UNICEF study on law reform identified sectorspecific reforms that could be seen as supportive of realisation of aspects of the CRC, while Goonesekere, commenting on law reform in sub-Sharan Africa, suggests that in some countries sector specific legislation supplementing a core children's statute may be more appropriate than wholesale incorporation, arguing that the breadth of coverage of the CRC means it is 'unrealistic to incorporate it totally as a single enactment enforceable in domestic law' (Goonesekere, 2007: 246; see also on CRC in the African context, Kaime, 2011).

Commentators often assert the value of incorporation. For example, Kilkelly suggests that incorporation at a constitutional level is a 'high water mark' of recognition for children's rights (Kilkelly 2011a, 145). Hoffman, drawing on insights from Wade, and Cassel on the instrumental value of human rights legislation more broadly, describes indirect incorporation as a 'normative' approach and suggests that legislation to embed human rights sends a message about 
children in society and confirms the application of children's rights to law and policy (Hoffman 2019 drawing on Cole 2012 and Cassell 2001; see also Edgar and Thwaites 2018; Arts 2014). Tobin meanwhile is more circumspect, commenting that incorporation does not tell us everything about the status of children in society, while recognising that incorporation can contribute to increasing respect for the rights of children as well as emphasising their legal status on the domestic level (Tobin 2005, 88) Thorburn Stern writing on incorporation in Sweden comments that raising the profile of children and children's rights was amongst the reasons for incorporation, while Lundy et al highlight how starting a debate on incorporation at the national level helps confirm children as rights-holders (Thorburn Stern 2019; Lundy et al., 2012). Thorburn Stern notes that the debate on incorporation in Sweden in part led to a discussion about children's legal status and whether it needs to be strengthened (Thorburn Stern 2019). Kilkelly, in contrast, comments that automatic incorporation avoids the risk associated with political or public debate which might result in a decision not to incorporate the $\mathrm{CRC}$, or to incorporate only select provisions, where national legislation is required (Kilkelly 2019). Lundy et al conclude that direct incorporation raises the profile of children's rights, and leads to children being more likely to be perceived as rights-holders and a culture of respect for children's rights (Lundy et al., 2012; see also Kaime 2011). Similarly, Hoffman and O'Neill in a 2018 study on the impact of indirect incorporation in Wales conclude that incorporation has raised the profile of children's rights in policy development and has empowered children as rights holders (Hoffman and O'Neill 2018).

An aspect of legal implementation not much discussed in the literature is how opportunities for incorporation arise. Alston and Tobin, in a report on legal and institutional aspects of implementation for UNICEF in 2005 comment that in States where authorities or traditions value constitutional expression or recognition of social policy a strong case can be made for incorporation following ratification (UNICEF 2005, 21). Drakeford and Sullivan draw attention to moments of significant constitutional change within States, such as that brought about by devolution, as opportunity to promote children's rights (Drakeford and Sullivan 2013). Williams, and also Hoffman demonstrate how devolution in Wales has allowed Welsh institutions to progress on indirect incorporation of the CRC at sub-State level (Williams 2013, Hoffman 2019). Bennett Woodhouse suggests that it is at times of constitutional change that the door is open to incorporation of rights, while Tobin observes that constitutions coming into effect after the CRC is adopted are more likely to reflect children's rights (Bennett Woodhouse 1999; Tobin 2005). Other research has also confirmed the relevance of coordination within government as well as between 
government and NGOs, the perceived importance of human rights, the extent of any pre-existing human rights culture, and political will as factors influencing incorporation of the CRC (e.g. Lundy et al., 2012).

\section{Impact on Enforcement}

A benefit often assumed for incorporation of the CRC is that it will lead to better enforcement of children's rights. It has been observed that the Committee does not have an effective mechanism to enforce the CRC at national level (e.g. ibid:; Hoffman, 2019; Sloth Nielsen, 2018). This has been described as the CRC's "Achilles heel" (Kilkelly, 2011b: 184). Alternative mechanisms and procedures to monitor compliance with human rights standards internationally have been developed. The mechanisms that apply to the CRC have been described by Balton as 'rather limited' and include periodic reporting by and examination of States Parties by the Committee (Balton, 1990: 127). However, the Committee has no power to enforce any recommendations it might make following such examination, and it has been observed that the Committee relies on 'diplomacy rather than legal sanction' (Kilkelly, 2001: 309; see also Donnelly, 2007, and Heyns and Viljoen, 2001). The Committee does not include enforcement in its description of incorporation, but does require that '[f] or rights to have meaning, effective remedies must be available to redress violations' (UN Committee 2003: para.24). Tobin argues that this means that it is implicit that a remedy should be provided where a child's rights are violated (Tobin, 2019).

In the general literature there is recognition of the potential of the courts to enforce human rights and to provide a remedy for violation (Edgar et al., 2018; Wind, 2016; Diver and Miller (eds.), 2016; El Boudouhi, 2015; Fauchald and Nollkaemper, 2012; Nolan 2011; Stein and Lord, 2008; Fatima, 2005). This is often inked to the status and legitimacy of human rights in the national legal system and legal culture. However, in particular in relation to socio-economic rights, commentators disagree about the role of judges to enforce international standards at national level (for an introduction to the debates on either side, see Gearty and Mantouvalou, 2013; see also Tobin, 2019, on the justiciability of social, economic and cultural rights in the context of the CRC). Although this debate is beyond the scope of this paper, it is worth noting that scholars on children's rights have also considered this issue, including in the context of incorporation. For example, Williams opines that children's marginalisation within the justice system, their limited resources and reliance on others to take action on their behalf undermines the effectiveness of court-based remedies (Williams, 2012). For Williams this suggests a stronger focus on incorporation 
of the CRC to promote deliberative processes of policy development, rather than a reliance on legal redress for violation (ibid.). Hoffman, also arguing for incorporation to focus on compliance through political rather than judicial mechanisms, contends that while integration of the CRC in national legal systems has a function to promote behaviours that deliver CRC consistent policy outcomes, there is a risk that reliance on court-based determination of children's rights will lead to rights becoming 'petrified into a "legalistic paradigm"' (Hoffman, 2019: 377, drawing on Koskenniemi, 1999: 99). Tobin comments that litigation remains an important strategy to secure realisation of the CRC, it tends to be 'reactive rather than preventive' and has a focus on 'addressing individual grievances rather than systemic change' (Tobin, 2019: 117).

Research shows that incorporation of the CRC and enforcement are not synonymous. Lundy et al., in their study for UNICEF-UK, found that children may not have any means of effective enforcement even in countries which had incorporated the CRC and where there were relatively comprehensive constitutional provisions for children (Lundy et al., 2012). Commentators have noted that if, and how, the CRC is enforceable depends not only on incorporation, but on the manner of incorporation and the standing given to the CRC in the national legal hierarchy. Kilkelly and O'Mahony suggest that how the CRC is incorporated is key to whether or not it leads to enforcement, and Thorburn Stern, in a recent study of incorporation of the CRC in Sweden, makes a similar point (Kilkelly and O'Mahony, 2007; Thorburn Stern, 2019). What is apparent, however, is that where the CRC is not incorporated, children or their representatives may have difficulty in obtaining redress for rights violations, particularly in those jurisdictions where human rights that have not historically been referred to as part of the national legal framework, or where judges are reluctant to accept the notion of children's rights (e.g. Lundy et al., 2012; Kilkelly, 2011). Liefaard and Doek, reflecting on an edited collection of studies on the CRC in domestic and international jurisprudence, conclude that in the absence of national laws to incorporate the CRC the courts may not see it as pertinent, and the justiciability of certain categories of children's rights may be called into question (Liefaard and Doek (eds.), 2015: 2).

Lundy et al., in the follow-up article to their 2012 study for UNICEF-UK, point out that incorporation provides opportunities for the CRC to be used in litigation but note that their study had not found evidence that incorporation leads to a flood of strategic litigation involving children (Lundy et al., 2013: 454). The authors conclude that in countries where direct enforcement is a possibility the main impact of incorporation was that the CRC was more likely to be cited in routine cases involving children (ibid.). Research for UNICEF in 2007 , based on a small number of examples, suggests that where there is direct 
incorporation, children's rights are more likely to feature and be influential in cases before judicial tribunals, and may provide some underpinning for administrative decision-making (UNICEF 2007a). Hoffman and O'Neill, in their report on the impact of indirect incorporation in Wales note that while this has potentially enhanced legal accountability, this has not emerged as a significant contribution toward accountability for children's rights compliance (Hoffman and O'Neill, 218).

A significant development in the context of incorporation and enforcement is how the CRC is regarded by regional human rights systems, and how it is applied by supra-national courts in the application and interpretation of regional human rights treaties. In the European context, Kilkelly observes that the European Court of Human Rights (ECtHR) increasingly uses the CRC to inform the interpretation of human rights guaranteed by the European Convention on Human Rights where children or their families are affected (Kilkelly, 2015). However, also at the European level, Stalford argues that the Court of Justice of the European Union (CJEU) is reluctant to engage with the CRC when exercising its jurisdiction in relation to EU law in application to children (Stalford, 2015). Smyth, however, points out that CRC rights are indirectly channelled into EU law through, for example, application of the Charter on Fundamental Rights of the European Union by the CJEU (Smyth, 2014). In the regional context of the Americas, Feria-Tinta notes that the Inter-American Court of $\mathrm{Hu}-$ man Rights deliberately and consistently uses the CRC to interpret the obligations of State parties under the American Convention on Human Rights (Feria-Tinta, 2015; see also Butler, 2005). In the African regional human rights system, the African Charter on the Rights and Welfare of the Child draws heavily on the CRC having been introduced to complement the CRC in the African context (Gyan Nyarko, 2018). However, the impact of the Charter at national level is debated. Sloth-Nielsen and Kruuse argue that the Charter (as well as the CRC) has influenced the jurisprudence of South African courts (SlothNielsen and Kruuse, 2013). Mbise, however, suggests that the CRC dominates and that the Charter is not well known amongst civil society, government or children and has 'remained in the shadows' of the CRC (Mbise: 1235).

\section{Impact on Policy}

Daly et al. observe that incorporation can lead to 'concrete change particularly in terms of ensuring regard is given to rights in policy development processes' (Daly et al., 2018: 5, referring to intermediate measures which others refer to as 
indirect incorporation). However, they also comment that the complexity of implementation makes it difficult to establish causation between legal measures and policy outcomes, and several commentators on incorporation of the CRC have drawn attention to the difficulty of confirming causation between incorporation and outcomes for children (ibid.; see also Harris-Short, 2003; Byrne and Lundy, 2015; Thorburn Stern, 2017; Hoffman and O'Neill, 2018). Another challenge for research in this area is identified by Polonko et al. who point at variation in the way incorporation is conceptualised makes it difficult to generalise about law reform in different States, which in turn makes comparative research on outcomes problematic (Polonko et al., 2016). Compounding this problem is the finding from research that even where States exhibit superficial similarities in their approach to international law, there are often internal differences which make comparative research problematic. Alston and Tobin, for example, note that while constitutional recognition should mean the CRC being fully acknowledged in domestic systems in monist States, in practice these States deploy various techniques to limit the practical impact of automatic incorporation (Alston and Tobin, 2005; see also Garcia Mendez, 2007).

Despite the challenges for research, in general, studies suggest that States that have incorporated international human rights are likely to be those in which conditions consistent with respect for rights, including children's rights, exist (Lundy et al., 2013). McCall-Smith argues that in States that have incorporated the CRC, there is a higher degree of implementation of children's rights than in countries which have chosen not to incorporate the CRC (McCallSmith, 2019). Lundy et al., in their study for UNICEF-UK, found that where there is incorporation, children are more commonly perceived as rightsholders and the CRC becomes an influential touchstone at national level for policy makers, and for advocates, but also that opportunities arise for strategic litigation (Lundy et al., 2012). They also found that incorporation can lead to States becoming 'increasingly creative as to how they approach the process of implementing the [CRC]', with the introduction of processes such as impact assessment that contribute to implementation and engage policy-makers with stakeholders (ibid:: 101). An example of this creative approach given by Kilkelly, as well as by Daly et al., is indirect incorporation in Wales (Kilkelly, 2019; Daly et al., 2018). Hoffman and O'Neil's research on indirect or quasi-incorporation in Wales suggests that it has been effective to raise the profile of children's rights within government, and has been influential on policy development, leading in some cases to better policy output (Hoffman and O'Neill, 2018). The research also confirms that indirect incorporation led to the introduction of Child Rights Impact Assessment, as well as structural innovations such as 
compulsory child rights training for all officials and a Child Right Advisory Group as a forum to engage civil society in policy development (ibid.). These are aspects of implementation recommended by the Committee, and which studies have confirmed are essential to effective realisation of children's rights (UN Committee 2003: para. 26 forward; Lundy et al., 2012). The relationship between legal implementation and non-legal measures is highlighted by Lundy et al. who observe that effective implementation of the CRC is 'highly contingent upon the measures adopted by a particular State', not just whether incorporation is a feature (Lundy et al, 2012: 19). And, as Tobin observes, ultimately the Committee is concerned with the 'cumulative impact' of all legislative measures and their contribution to implementation in practice (Tobin, 2019: 115).

\section{$9 \quad$ Synthesis}

On one view incorporation may be understood as a malleable concept which might involve a range of processes taking place over time to internalise or absorb international norms into national law and practice. Other accounts are more prescriptive, focusing on constitutional systems and processes for making international law treaties applicable at the domestic level, with less consideration given to the effect this has within national systems. What emerges from the literature is both a diverse terminology to describe incorporation, and differences of understanding about what this should mean in practice. This extends to the relationship between incorporation and enforcement. In some accounts this is assumed, in others the connection remains unclear until established by legislation or application by national judiciary. Literature on incorporation of the CRC engages with the wider literature in some areas, in particular to highlight how constitutional arrangements (monist/dualist) and justice systems (common law/civil law) impact on how incorporation takes place. However, what is also apparent is that a paradigm typology has emerged to describe modes of incorporation in application to the CRC which adopt some of the terminology and analysis in the general literature, but seems to be more firmly established in the child rights researchers' lexicon, and more embedded as a way of describing the diversity of incorporation of the CRC in practice. What is also apparent is that in many respects this typology departs from more formal accounts of incorporation of human rights treaties and international law generally. An issue for scholars is the extent to which this has given rise to fragmentation between child rights discourse and human rights discourse more widely, and the possible impact of this for future conceptual 
and comparative research, and studies on the significance of incorporation for implementation. ${ }^{5}$ It is also worth noting that the typology of incorporation now commonly deployed in the child rights literature departs from the expectations of incorporation established by TMBs and in particular the Committee. Despite this, it may be seen as useful to describe incorporation of the CRC in different countries and therefore to facilitate discussions about prevalence. Adopting the typology, research has confirmed that incorporation in some form is a feature in many States that are party to the Convention, but that full and direct incorporation is less significant, with many States favouring the sectoral approach which means less disruption to the national legal order (especially at the constitutional level), and which engages most obviously with narrow areas of policy and practice that are traditionally regarded as having an impact on children.

While there is a considerable body of research on the Convention, legal measures of implementation and law reform, there are hardly any studies that focus exclusively on the impact of incorporation. There is a clear need for research in this area, and for research to differentiate and delineate more explicitly the impacts from the various approaches encountered in practice. The typology of incorporation tends to be employed loosely in child rights research, making it challenging to establish the impact of particular modes of incorporation.

With some exceptions, accounts of legal implementation of the Convention begin by describing its status in national law, with less attention to the social or political conditions which influence whether or not, and how, incorporation takes place, or the strategies adopted by campaigners in response to these conditions. In those studies that have examined impact there is a tendency to generalise from generic understandings of incorporation, or analysis is necessarily confined to a relatively small sample from which it is difficult to extrapolate to different constitutional or jurisdictional systems. A particular issue for research is the lack of evidence to confirm the strengths and weaknesses of different approaches to incorporation, which inhibits comparative analysis. However, despite limitations, there is a developing body of evidence to confirm that incorporation has an instrumental value, in particular to signal the status of children and children's rights within society, and to confirm children as rightsholders. The available research also confirms that incorporation can lead to better recognition of children's rights by the courts and increased visibility of the Convention in litigation, as well as providing opportunities for strategic

5 Cantwell has discussed the perils of treating children's rights (and the CRC) as something different to human rights law in general (Cantwell, 2011). 
litigation. However, the evidence does not suggest that enforcement and opportunities to enforce rights through litigation as the primary impacts of incorporation. Rather, incorporation may be seen as potentially having a range of impacts. These include influencing administrative decision-making and policy, leading in some cases to policy more consistent with children's rights. What is often unclear, however, is how incorporation is a factor in policy development alongside other legal and non-legal measures of implementation, and if or how this leads to better outcomes for children.

\section{Acknowledgements}

Rebecca Thorburn Stern's research for this article is generously funded by the Ragnar Söderberg Foundation.

For practical reasons the review undertaken in this paper focuses on research published in the English and Scandinavian languages. Without doubt, research published in other languages would provide additional insights.

\section{References}

Alston, P. (ed.), The EU and Human Rights (Oxford: Oxford University Press: 1999).

Alston, P. and Goodman, R., International Human Rights (Oxford, Oxford University Press: 2013).

Alston, P. and Tobin, J., Laying the foundations for children's rights: An independent study of some key legal and institutional aspects of the impact of the Convention on the Rights of the Child (UNICEF: 2005).

Arts, K., "Twenty Five years of the UNCRC: Achievements and Challenges", Netherlands International Law Review, 2005, LXI: 267-303.

Balton, D., "The Convention on the Rights of the Child: prospects for international enforcement", Human Rights Quarterly, 1990, vol. 12, 120-129.

Beco, G. de, "The Option Protocol to the Convention on the Rights of the Child on a Communications procedure: good News?", Human Rights Law Review, 2013, 13(2), 367-87.

Bennett Woodhouse, B., (1999), "Recognising children's rights: lessons from South Africa", Human Rights, 1999, vol. 26, 5-18.

Björgvinsson, D.T., The intersection of international law and domestic law: A theoretical and practical analysis (Cheltenham, Edward Elgar: 2016).

Boyle, K., Models of Incorporation and Justiciability for Economic, Social and Cultural Rights (Edinburgh, Scottish Human Rights Commission: 2018). 
Bring, O., Mahmoudi, S. and Wrange, P., Sverige och folkrätten (Stockholm, Norstedts Juridik: 2014).

Butler, I. de J., "The Right of the Child in the Case Law of the Inter-American Court of Human Rights: Recent Cases United Nations and Regional Human Rights Systems: Recent Developments", 20055 Human Rights Law Review, 151-168.

Byrne, B. and Lundy, L., "Reconciling Children's Policy and Children's Rights: Barriers to Effective Government Delivery', Children and Society, 2015, 29, 266-276.

Campbell, T., "Incorporation through Interpretation" in Ewing K.D. and Tomkins Adam, Sceptical Essays on Human Rights (Oxford, OU P: 2001), 79-102.

Cantwell, N., "Are Children's Rights Still Human?" in Invernizzi, A. and Williams, J. (eds.), The Human Rights of Children, From Visions to Implementation (Farnham, Ashgate: 2011).

Cassel, D., "Does International Human Rights Law Make a Difference", Chicago Journal of International Law 2, 2001, No. 1, Article 8, 121-35.

CESCR (1998), Committee on Economic, Social and Cultural Rights, General Comment No. 9, Domestic application of the Covenant, 1998.

Cole, W.M., "Human Rights as Myth and Ceremony? Reevaluating the Effectiveness of Human Rights Treaties 1981-2007", American Journal of Sociology, 2012, 17, No. 4, 1136.

Crawford, J.R., Brownlies principles of public international law (Oxford, Oxford University Press: 2012).

Daly, A., McDermott-Rees, Y. and Curtis, J., Enhancing the Status of UN Treaty Rights in Domestic Settings (Manchester, Equality and Human Rights Commission: 2019).

Diver, A., and Miller, J., (eds.), Justiciability of Human Rights Law in Domestic Jurisdictions (Springer: 2016).

Donnelly, J., International Human Rights (Colorado, Westview Press: 2007).

Drakeford, M. and Sullivan, M., "Made to Measure: cooperation and conflict in the making of policy" in Williams, J. (ed.), The UNCRC in Wales (Cardiff, University of Wales Press: 2013).

Edgar, A. and Thwaites, R., "Implementing Treaties in Domestic Law: Translation, Enforcement and Administrative Law", 2018, 19 Melbourne Journal of International Law 24.

Egede, E., "Bringing Human Rights Home: An Examination of the Domestication of Human Rights Treaties in Nigeria”, 2007, Journal of African Law, vol. 91, No. 2.

El Boudouhi, S., "The National Judge as an Ordinary Judge of International Law? Invocability of Treaty Law in National Courts", 2015, Leiden Journal of International Law, 28.

Fatima, S., Using International Law in Domestic Courts (Oxford and Portland, Hart Publishing: 2005). 
Fauchald, O.K. and Nollkaemper, A., The practice of international and national courts and the (de-)fragmentation of international law (Oxford and Portland, Hart: 2012).

Feria-Tinta, M., "The CRC as a Litigation Tool Before the Inter-American System of Protection of Human Rights" in Liefaard, T., Doek, J.E., (eds.), Litigating the Rights of the Child. The UN Convention on the Rights of the Child in Domestic and International Practice (Dordrecht, Springer: 2015).

Garcia Mendez, E., "A comparative study of the impact of the CRC: Law reform in selected civil law countries" in UNICEF, 2007.

Gearty, C. and Douzinas, D. (eds.), The Cambridge Companion to Human Rights Law (Cambridge, CUP: 2012).

Gearty, C. and Mantouvalou, V., Debating Social Rights (Oxford, Hart Publishing: 2013).

Goonesekere, S., "Law Reform and Children's Rights in Plural Legal Systems: Some Experiences in Sub-Sharan Africa" in UNICE F, 2007.

Gyan Narko, M., "Towards Effective Implementation of the African Charter on the Rights and Welfare of the Child in Egypt", 201811 African Journal of Legal Studies, 141-177.

Harrington, J., "The Democratic Challenge of Incorporation: International Human Rights Treaties and National Constitutions", 2007 Victoria University of Wellington Law Review, 38, 217-36.

Harris-Short, S., "International human rights law: imperialist, inept and ineffective? Cultural relativism and the UN Convention on the Rights of the Child", 2003 Human Rights Quarterly, vol. 25, No. 1, 130-181.

Heyns, C. and Viljoen, F., "The impact of the UN human rights treaties at domestic level" Human Rights Quarterly2001, vol. 23, 483-535.

Hoffman, S., "The UN convention on the rights of the child, decentralisation and legislative integration: a case study from Wales", 2019 The International Journal of Human Rights, Vol. 23(3), 374-391.

Hoffman, S. and O'Neill, S., The Impact of Legal Integration of the UN Convention on the Rights of the Child in Wales (Cardiff, Equality and Human Rights Commission: 2018).

Hoffman, S. and Williams, J., "Accountability" in Williams, J. (ed.), The UNCRC in Wales (Cardiff, University of Wales Press: 2013).

Human Rights Committee, General Comment No. 3, Implementation at the national level (1981).

Human Rights Committee, General Comment No. 31, The Nature of the General Legal Obligation Imposed on States Parties to the Covenant (2004).

Invernizzi, A. and Williams, J. (eds.), The Human Rights of Children, From Visions to Implementation (Farnham, Ashgate: 2011).

Inter-American Court of Human Rights, Advisory Opinion on Juridical Condition and Human Rights of the Child, OC-17/02, 28 August 2002. 
Kaime, T., The Convention on the Rights of the Child: a cultural legitimacy critique (European Law Publishing: 2004).

Kilkelly, U., “The best of both worlds for children's rights: interpreting the European CRC on Human Rights in the light of the UN Convention on the Rights of the Child", 2001 Human Rights Quarterly, vol. 23, No. 2, 308-326.

Kilkelly, U., "The CRC at 21: assessing the legal impact", Northern Ireland Legal Quarterly, 2011, vol. 62, No. 2, 143-152.

Kilkelly, U., "Using the Convention on the Rights of the Child in Law and Policy" in Invernizzi, A. and Williams, J. (eds.), The Human Rights of Children, From Visions to Implementation (Farnham, Ashgate: 2011).

Kilkelly, U., "The CRC in Litigation under the ECHR" in Liefaard, T., Doek, J.E., (eds.), Litigating the Rights of the Child. The UN Convention on the Rights of the Child in Domestic and International Practice (Dordrecht, Springer: 2015).

Kilkelly, U., "The UN convention on the rights of the child: incremental and transformative approaches to legal implementation", 2019 The International Journal of $\mathrm{Hu}$ man Rights, 23(3), 323-337.

Kilkelly, U. and Liefaard, T. (eds.), International Human Rights of Children (Dordrecht, Springer: 2018).

Kilkelly, U. and O'Mahony, C., “The proposed children's rights amendment: running to stand still?", 2007 Irish Journal of Family Law, vol. 2, 19.

Koh, H.H., "How is International Human Rights Law Enforced?", 1999 Indiana Law Journal, 74 .

Koskenniemi, M., "The Effects of Rights on Political Culture" in Alston, P. (ed.), The EU and Human Rights (Oxford: Oxford University Press: 1999).

Leary, V., International Labour Conventions and National Law. The Effectiveness of the Automatic Incorporation of Treaties in National Legal Systems (Netherlands, Springer: 1982).

Liefaard, T., Doek, J.E., (eds.), Litigating the Rights of the Child. The UN Convention on the Rights of the Child in Domestic and International Practice (Dordrecht, Springer: 2015).

Lundy, L., Kilkelly, U. and Byrne, B., The UNConvention on the Rights of the Child: A comparative study of legal implementation in 12 countries (London, UNICEF-UK: 2012).

Lundy, L., Kilkelly, U. and Byrne, B., "Incorporation of the United Nations Convention on the Rights of the Child in Law: A Comparative Review", 2013 The International Journal of Children's Rights, 21, 442-463.

McCall-Smith, K., "To incorporate the CRC or not - is this really the question", 2019 The International Journal of Human Rights, 23(3), 425-441.

Mbise, A.T., "The diffusion of the United Nations Convention on the Rights of the Child (UNCRC) more than the African Charter on the Rights and Welfare of the Child (ACRWC) in Africa: The influence of coercion and emulation", 201760 International Social Work 5, 1233-1243. 
Mihr, A. and Gibney, M. (eds.), The SAGE Handbook of Human Rights (London, SAGE: 2014).

Nolan, A., Children's socio-economic rights, democracy and the courts (Oxford, Hart, Publishing: 2011).

Nollkaemper, A., National courts and the international rule of law (Oxford, Oxford University Press: 2012).

Oberleitner, G., "Does enforcement matter" in Gearty, C. and Mantouvalou, V., Debating Social Rights (Oxford, Hart Publishing: 2012).

Polonko, K.A., Lombardo L.X. and Bolling, I.M., "Law Reform, Child Maltreatment and the UN Convention on the Rights of the Child", 2016 International Journal of Children's Rights, (4) 29-64.

Resnik, J., "Law's Migration: American Exceptionalism, Silent Dialogues, and Federalism's Multiple Ports of Entry", 2006115 Yale Law Journal 1564.

Ruck, M., Peterson-Badali, M. and Freeman, M. (eds.), Handbook of Children's Rights. Global and Multidisciplinary Perspectives (New York, Routledge: 2017).

Sandberg, K., “The role of national courts in promoting children's rights. The case of Norway", 2014 International Journal of Children's Rights, 22(1).

Sandholtz, W. and Whytock, C. (eds.), Research Handbook on the Politics of International Law (Edward Elgar Publishing: 2017).

Scheinin, M., (1996), 'General Introduction' in Scheinin, M., (ed.), International Human Rights Norms in the Nordic and Baltic Countries (The Hague/London/Boston, Martinus Nijhoff Publishers: 1996).

Scheinin, M., (ed.), International Human Rights Norms in the Nordic and Baltic Countries (The Hague/London/Boston, Martinus Nijhoff Publishers: 1996).

Skelton, A., "International Children's Rights Law: Complaints and Remedies" in Kilkelly, U. and Liefaard, T. (eds.), International Human Rights of Children (Dordrecht, Springer: 2018).

Sloth Nielsen, J., “Monitoring and Implementation of Children's Rights” in Kilkelly, U. and Liefaard, T. (eds.), International Human Rights of Children (Dordrecht, Springer: 2018).

Sloth-Nielsen, J. and Kruuse, H., "A Maturing Manifesto: The Constitutionalisation of Children's Rights in South African Jurisprudence 2007-2012", 2013 International Journal of Children's Rights, 646-678.

Sloss, D., (ed.), Treaty Enforcement: A Comparative Study (Santa Clara University: 2009). Smith-Cannoy, H., "Mainstreaming Human Rights" in Mihr, A. and Gibney, M. (eds.), The SAGE Handbook of Human Rights (London, SAGE: 2014.

Smyth, C., European Asylum Law and the Rights of the Child (Routledge, London and New York: 2014).

Søvig, K.H., "Barnets rettigheter på barnets premisser - utfordringer i møtet mellom FNs barnekonvensjon og norsk rett" (Bergen, Det juridiska fakultet: 2009). 
Stalford, H., "The CRC in Litigation under EU Law" in Liefaard and Doek (eds.), Rights of the Child. The UN Convention on the Rights of the Child in Domestic and International Practice (Dordrecht, Springer: 2015).

Stein, M. and Lord, J., "The Domestic Incorporation of Human Rights Law and the United Nations Convention on the Rights of Persons with Disabilities", 200883 Washington University Law Review 9.

Stern Thorburn, Implementing Article 12 of the UN Convention on the Rights of the Child: Participation, Power and Attitudes (Leiden and Boston, Brill/Nijhoff: 2017).

Thorburn Stern, R., "Much Ado about Nothing? The Road to the Incorporation of the Convention on the Rights of the Child in Sweden", 2019 International Journal of Children's Rights, 27(2), 266-305.

Tobin, J., "Increasingly seen and heard: the constitutional recognition of children's rights", 2005 South African Journal on Human Rights, vol. 21.

Tobin, J., "Article 4. A State's General Obligation of Implementation" in Tobin, J. (ed.), The UN Convention on the Rights of the Child. A Commentary (Oxford, Oxford University Press: 2013).

Tobin, J. (ed.), The UN Convention on the Rights of the Child. A Commentary (Oxford, Oxford University Press: 2013).

UN Committee, Committee on the Rights of the Child, General Comment No. 5 , General Measures of Implementation of the Convention on the Rights of the Child, 2003.

UN Committee, Committee on the Rights of the Child, General Comment No.19, On public budgeting for the realization of children's rights, 2013.

UNICEF, Study on the impact of the Implementation of the Convention on the Rights of the Child (Innocenti Research Centre, Florence: 2004).

UNICEF, The General Measures of the Convention on the Rights of the Child: The Process in Europe and Central Asia (Innocenti Research Centre, Florence: 2006).

UNICEF, Protecting the World's Children: Impact of the CRC in Diverse Legal Systems (Cambridge, Cambridge University Press: 2007a).

UNICEF, Law Reform and the Implementation of the Convention on the Rights of the Child (Innocenti Research Centre, Florence: 2007b).

UNICE F, Global Perspectives on Consolidated Children's Rights Statues (UNICE F: 2008). Van Alstine, M.P., “The role of domestic courts in treaty enforcement" in Sloss, D., (ed.), Treaty Enforcement: A Comparative Study (Santa Clara University: 2009).

Vandenhole, W., Desmet, E., Reynaert, D. and Lembrechts, S. (eds.), The Routledge International Handbook of Children's Rights Studies (London, Routledge: 2015).

VCLT, Vienna Convention on the Law of Treaties (No.18232), 23 May 1969.

Venice Commission, European Commission for Democracy through Law, Report on the implementation of international human rights treaties in domestic law and the role of the courts (Council of Europe, Strasbourg: 2014). 
Verdier, P-H and Versteeg, M. (2017), "Modes of domestic incorporation of international law" in Sandholtz, W. and Whytock, C. (eds.), Research Handbook on the Politics of International Law (Edward Elgar Publishing: 2017).

Williams, J., "Incorporating children's rights: the divergence in law and policy", 2007 Legal Studies, vol. 27. no. 2, 261-287.

Williams, J., "General legislative measures of implementation: individual claims, 'public officer's law' and a case study on the UNCRC in Wales", 2012 International Journal of Children's Rights, vol. 20, 224-240.

Williams, J., "The Rights of Children and Young Persons (Wales) Measure 2011 in the context of the international obligations of the UK" in Williams, J. (ed.), The UNCRC in Wales (Cardiff, University of Wales Press: 2013).

Williams, J., "England and Wales" in Liefaard, T., Doek, J.E., (eds.), Litigating the Rights of the Child. The UN Convention on the Rights of the Child in Domestic and International Practice (Dordrecht, Springer: 2015).

Williams, J. (ed.), The UNCRC in Wales (Cardiff, University of Wales Press: 2013).

Wind, M., "Do Scandinavians Care about International Law? A Study of Scandinavian Judges' Citation Practice to International Law and Courts", 2016, Nordic Journal of International Law. 